\title{
A Study on Punjabi Cuisine and Its Role in Tourism Development
}

\author{
Mr. Vikash kumar, Mr. Sudheer kumar \\ Ranjita Institute of Hotel Management \& Catering Technology, IHM, Jaipur
}

\begin{abstract}
This case study analyses the regional cuisine of Punjab and its symbiotic relationship with the concept of rural tourism. Rural tourism in Punjab, a scheme promoted by Punjab Heritage and Tourism Promotion Board, is a concept which gives a viable and sustainable direction to the broader canvas of Rural Tourism. Importance of Tourism development can not be overstated, for India's future growth, as a large scale employment generator, income distributor and as a relatively greener industry. For the sustainability of tourism industry and from a marketing perspective it is important that tourism policy is aimed at broad basing the attractions and diversifying the perception of tourism from traditional run-of-the-mill 'Beach-Hills-Forts' trio. The cuisine of Punjab is rich in flavour, high in calories, spicy and hearty. The facile methods, seasonal availability of ingredients make it quite a flexible cuisine. Sarson da saag, Makki di roti, Tandoori murga .... are few dishes which have placed Punjab on the world culinary map. Dhabas, serving the convenience food for the travelers, have popularized the Punjabi cuisine in a new way. Exploratory nature of tourists brings them to Punjab. Being an agricultural state, rural tourism is booming in the state.
\end{abstract}

Keywords: Rural Tourism, Regional Cuisine, Punjab, Alternative Tourism, Niche Marketing , Sustainability , Environmental Concerns, Rural Employment.

\section{Introduction}

India is a journey into mysticism. This is one place where you can travel through 5000 years of history, culture and civilization. It is covered on one side by the mighty peaks of a mountain that towers above everything else in the world and on the other hand it merges into the vastness of the blue waters. In between there are plains depicting a rich culture, heritage and traditions. It's a huge canvas of myriad hues covering desert, forests, backwaters, colorful costumes, festivals and delectable fare of diverse cuisines.

It's a wonder that one of the world's most scintillating destination -India-which is metaphorically speaking comparable to a living museum has failed to realize its tourism potential. However, previous one decade has seen a slow but sure progress and we are today among the fastest growing tourism economies in the world. It is manifested in the fact that in the year 2009 we received 5.11 million tourists and India's rank in world tourism arrivals and world tourism receipts now stand at 41 and 22 respectively. (source: tourism. govt. in-official website of MOT-GOI)

This certainly is an encouraging sign. India's growing clout in the world as a financial powerhouse as well as recognition of India's soft-power is sure to translate into world to sit-up and take notice. It also means substantial increase in tourist footfalls in coming one decade. The question is whether we are prepared for it? In terms of infrastructure there is a steady growth but it still needs a great deal of improvement to be termed as truly of international standard. However, that is beyond the scope of this paper and here the point of discussion is whether this kind of tourism growth along with the manifold increase in domestic tourism going to be sustainable. The concept of niche tourism is still not explored by the tourism industry here and mass tourism is having an adverse impact on already fragile ecological balance of several destinations. In the above background, this study highlights a tourism model known as 'Rural Tourism' and the use of regional cuisine in a symbiotic relationship with rural tourism to promote each other.

Before discussing the rural tourism and regional cuisine model we would like to give a brief overview of Punjab state and also about the broad concept of rural tourism.

\section{Review Of Literature}

Community based tourism has been a sustainable tourism initiated and operated by local and indigenous people. further it has been sum total of various forms of tourism like eco-tourism, sustainable tourism and all those branches of tourism, which have kept into consideration community well being prior to tourism business. Both responsible tourism and pro-poor tourism are approaches to tourism with an emphasis on community participation, rather than tourism as a product or sector (Ashley, Roe \& Goodwin , 2001).

Local communities are basic element of modern tourism development. They are the focal point for the supply of accommodation, catering, information, transport, facilities and services for tourism development (Godfrey \& Clarke, 2000). The term community can have a specific geographical meaning with a clearly defined spatial boundary and area and also refers to groups of people with a common interest (Chapman \& Kirk, 
2001). Community is defined as a group of individuals living or working within the same geographic area with some shared cultures or common interests. Community development can be seen as building social capital for collective benefits. It uses skill and knowledge and strategy in their practice (Gilchrist, 2004).

Local communities are a main reason for tourists to travel, to experience the way of life and material products of different communities. Local communities also shape the 'natural' landscapes, which many tourists consume. Communities are, of course, also the source of tourists; tourists are drawn from particular places and social contexts which in themselves will help shape the context of the tourist's experience in the host community (Richards \& Hall, 2000). As per Malhotra R.K.( 1998), like any business or industry, tourism needs the moral and financial support of the entire community. The development of tourism in local communities is often an illustration of a community taking advantage of resources within community, which is an example of self-help approaches to community development which is a strategy of community development in tourism development (Christenson, 1989).

Rural tourism is currently the focus of attention throughout the world and is being recognized as an important instrument of growth for the rural economy. Rural tourism showcases the rural life, art, culture and heritage at locations. It is a multi-faceted and entails Agri-tourism, Cultural tourism, Nature tourism, Adventure tourism and Eco-tourism. As against conventional tourism, rural tourism has certain unique features such as; it is experience oriented, the locations are sparsely populated, predominantly in natural environment, meshes with seasonality and local events and based on presentation of culture, heritage and traditions. Today, the importance of tourism and the necessity of conducting research on it because of significant economic, and social, and cultural roles that it can play is known for everyone. It had turned into one of the most important factors to create wealth, job, dynamism, moving people, and national assets (Moshabaki and Malek, 2004). Rural tourism development has always been a valuable, growing economic strategy, and an advantage of low risks and costs and considering that resources are available, costs are low and plans are smaller compared to other tourism plans (projects). It helps to economic growth, create variety and stability in employment, dynamism in commerce and industries, creating opportunities to larger incomes in multiple activities, creating new markets for agricultural products and enhance a basis for the regional economy. One of the most important features of rural tourism economy is the motivation that the private sector has for investment in tourism because it is small, varied and simple. It is a rather important field in rural development which can build up opportunities and facilities especially for employment and regional income and play a crucial role in reviving and rebuilding rural regions. The role and importance of tourism In the process of rural development had been proved in many countries. The importance of rural tourism as a part of the overall tourism market depends on each country's recreation/tourism resources, infrastructure image, market access and the presence of other type of tourism products. Even if rural tourism may be minor in relation to the overall tourism market of many countries, its importance to the development of specific rural areas may be critical. Thus, the multiplier effect is often more impacting in rural areas where the entire rural lifestyle is located for a main attraction. Planners are using rural tourism, which also includes eco tourism and farm tourism to increase economic opportunities for the rural people. The motivation behind rural is to escape limitations and the urban routine life and the regulations opposite to the free will and voluntary entertainment. Rural tourism's greatest potential benefit is its ability to generate money which can translate in to numerous positive economic opportunities for locals and their communities. For local the first benefit of tourism development is jobs both within the tourism sector and outside of it. Tourism development means more income and profits for tourist related business. The economic multiplier model suggests that if local income from tourist expenditures is spent within local area, an increase in local income and jobs will follow (Indolia, 2012).

\section{Research Objective}

* To highlight the importance of rural tourism in the overall tourism eco system

* To enumerate the role of regional cuisine in the success of rural tourism model

\section{Research Method}

\section{Research Methodology}

This study utilized both primary and secondary data to bridge the Gap between Hospitality Education and Hospitality Industry.

\section{Primary Data \\ Qualitative Approach}

The study was conducted using qualitative research methodology. This was used to help the researcher seek the views of hospitality/tourism tertiary graduates to provide key information about the needed skills that they consider as being important for the students. As qualitative research, respondents were offered the opportunity to respond to questions more elaborately. 


\section{Instrumentation}

The primary data through questionnaire was collected through semi-structured, personal in depth interviews conducted with both educators of and industry professionals working in Lodging, Management and Food and Beverage Industry. Semi structured interviews are more flexible and allows the interviewer to probe into issues and in some cases follow the order dictated by the situation. Consequently, hospitality graduates were selected to provide key information about the needed skills that they consider as being important for the students. The reason for the choice is that, they may have actually experienced what was taught in class and what was useful in the workplace. The interview was conducted at the respondent's work place and hospitality management organizations and it took about 30 minutes for each respondent.

Secondary data was used to compare previous years research regarding tourist preferences as Punjabi food. The data selected by secondary data collected in a longitudinal manner. The studies were similar but maintained little difference in supporting questions.

\section{Scope and Limitations of Study}

- The study is dependent on having access to people \& organizations at times with some reason access was denied or limited in some way.

- The time available to investigate a research problem and to measure change or stability over time further added to the limitations of the survey.

- The incomplete filling of questionnaire did not lead to concrete result.

- Had money not been a constraint, the research could have been made more comprehensive

\section{Punjab State-An Overview}

Punjab is known as land of five rivers. The Punjab Govt. has give tourism a special status by declaring it as an industry in the year 1996. The state does not have much to offer as far as natural resources are concerned. But state has excellent infrastructure as compared to other states, which is helpful in attracting tourists. The tourism product of Punjab is varied and rich in culture and heritage, food, festivals, fairs, local arts and crafts, palaces, monuments, religious places and much more. (www.oppapers.com-nainni/business and economy.)

However, the most vibrant image of Punjab is its people. The robust, full of joy, full of life Punjabis and their legendry hospitality is a part of folk lore. Their dances, music, cuisine, attitude towards life, almost everything is larger than life. There is nothing ordinary abut a true Punjabi. Therefore, in terms of tourism product the most sellable item here is the life-style of Punjab and an experience of this life-style. This is possible only if a tourist visits a rural site or to be more precise a village of Punjab.

\section{Rural Tourism in Punjab:}

The tradition and culture of Punjab has always casted a strong influence on the rest of India. Here, the trip remains incomplete without a visit to its farms; an integral part of the lives of Punjabi locals. The warmth and affection of the people is legendary. The best place to experience their large- heartedness is on the farms of Punjab.

Punjab is a state in the northwest of the Republic of India, forming part of the larger Punjab region. The state is bordered by the Indian states of Himachal Pradesh to the east, Haryana to the south and southeast and Rajasthan to the southwest as well as the Pakistani province of Punjab to the west. It is also bounded to the north by Jammu and Kashmir. Tourism in Indian Punjab centres around the historic palaces, battle sites, and the great Sikh architecture of the state and the surrounding region. Examples include various sites of the Indus Valley Civilization, the ancient fort of Bathinda, the architectural monuments of Kapurthala, Patiala, and Chandigarh, the modern capital designed by Le Corbusier. The Golden Temple in Amritsar is one of the major tourist destinations of Punjab and indeed India, attracting more visitors than the Taj Mahal, Lonely Planet Bluelist 2008 has voted the Harmandir Sahib as one of the world's best spiritual sites. Moreover, there is a rapidly expanding array of international hotels in the holy city that can be booked for overnight stays. The Indian state of Punjab is known for its cuisine, culture and history. Some of the main cities in Punjab are Amritsar, Jalandhar, Ludhiana and Patiala. Punjab's public transportation network provides excellent tourist transportation. Tourists to Punjab can enjoy culture, ancient civilization, spirituality and history. Punjab has a rich religious history incorporating Sikhism, Islam and Hinduism. The royal Punjabi palaces, historic battle sites, shrines, temples and examples of Sikh architecture are notable attractions. Punjabi cuisine includes a wide range of both vegetarian and nonvegetarian dishes. Due to the scope and depth of Punjab's history there are many places of interest. Tourism is a swiftly expanding sector in Punjab. Focusing on existing rich culture of the State, Punjab Government has decided to give a major fillip to tourism and promote rural tourism in the State. For the purpose, the Government has identified a cluster of four villages namely Katli, Bahadarpur, Tibba Tapparian and Ranjitpura Bas in Rupnagar district which would be developed with the entire infrastructure needed to provide a new experience 
to the tourists visiting the State. In order to tap the potential, there is a dire need to focus on certain key issues such as participation of local government, efficient tourism promotion and development programs, cooperation between local government and entrepreneurs and community support for tourism development are essential for successful tourism in Punjab.

\section{Regional Cuisine of Punjab:}

The cuisine of Punjab has an enormous variety of mouth-watering vegetarian as well as non vegetarian dishes. The spice content ranges from minimal to pleasant to high. Punjabi food is usually relished by people of all communities. In Punjab, home cooking differs from the restaurant cooking style. At the restaurants, the chefs make a liberal use of desi ghee, butter and cream to make the food lip smacking and finger licking. On the other hand, at home, people prefer using sunflower oil or some other refined oil for cooking, with the basic idea of making the food low in fat content.

Wheat is the staple food of Punjabis; however, they do enjoy eating rice on festivities and other special occasions. When it comes to food, each region in Punjab has an entirely different preference like people in Amritsar are particularly fond of stuffed paranthas and milk products. The philosophy of life for most of the Punjabis is to eat, drink and make merry. They are real lively people who are extremely fond of eating good food. In the preparation of Punjabi food, onion, ginger and garlic are used extensively to enhance the taste of the food.

Punjabi people are robust people with robust appetites and their food is like the Punjabis themselves, simple, sizeable and hearty with no unnecessary frills or exotic accompaniments. The Punjabi tandoori cooking is celebrated as one of the most popular cuisines throughout the world. Huge earthen ovens are half buried in the ground and heated with a coal fire lit below it. Marinated meat, chicken, fish, paneer, rotis and naans of many types are cooked in this novel oven and the results are absolutely scrumptious! Punjab has imbibed some aspects of its cuisine from external influences. Connoisseurs of the cuisine say that the gravy component of Punjabi cuisine came from the Mughals. The most popular example is the murg makhani. It served the state well to combine this influence in its cooking since it had a lot of pure ghee and butter. Murg makhani also provided a balance to tandoori chicken, which was dry because it was charcoal cooked. Nans and parathas, rotis made of maize flour are typical Punjabi breads. Of course, over the years the roti has been modified to add more variety, so there is the rumali roti, the naan and the laccha parathas, all cooked in the tandoor.

Winter, in Punjab, brings in the season of the famous makki ki roti(maize flour bread) and sarson ka saag(mustard leaf gravy). No meal is complete without a serving of lassi( sweet or salted drink made with curd) or fresh curd and white butter which is consumed in large quantities. The other popular dishes, which belong exclusively to Punjab, are ma ki dal, rajma (kidney beans) and stuffed parathas. Punjab, the land of milk and honey, boasts of a robust climate where the agricultural revolution has reaped rich dividends. The land of plenty has a cuisine, which caters to the characteristic needs of the people.

Punjabi cuisine is not subtle in its flavor. There are no intricate marinades or exotic sauces but it has full-bodied masalas (spices) cooked with liberal amount of desi ghee (clarified butter) always served with a liberal helping of butter or cream. Milk and its products are an essential part of every day cookery, curd and buttermilk are also an essential concomitant with every Punjabi meal.

\section{Symbiotic Relationship of Regional Cuisine and Rural Tourism:}

Cuisine plays an important role in tourism of any state but is not widely considered as a hell raising factor in improving the tourism inflow but in case of Punjab this factor up to some extent has been proved wrong, here after culture cuisine holds a large share in creating the perception of the tourists. People of different languages, culture, customs and races have influenced Punjab's culture for 1000 of years, this is what makes their lifestyle unique. whether it's the stunning and vibrant hues of their apparel or the lip smacking taste of a Dal Makhani, Punjab is a celebration of life. Rural tourism is all about authenticity of the experience. While in urban restaurants the food that is served on the name of authentic cuisine vastly differs from the ethnic cuisine as the ingredients used, utensils and method of cooking can not be replicated of the original recipes. Moreover, commercial compulsions have made the service providers in hotels and restaurants to greatly compromise the authenticity of the cuisine. Rural tourism on the other hand provides vastly authentic cuisine as the ingredients, method, utensils, set-up and recipe every thing retains its original flavor. Therefore, one may safely conclude that rural tourism provides the best platform for cuisine to survive in its original form and cuisine gives the pull factor for the tourists to come to rural vista and enjoy this form of tourism. Therefore it is said that regional cuisine and rural tourism are in a symbiotic relationship. 


\section{Conclusion}

Tourism product in India is hugely varied ranging from cool retreats to beaches, desert to wildlife, spirituality to heritage, wellness to adventure sports and MICE to Rural tourism. However, tourism industry in India is not able to utilize this splendid product range and instead has focused only on conventional 'beacheshills-forts' troika. This research paper aims at bringing forward the concept of rural tourism in the state of Punjab and the role and impact of regional cuisine in rural tourism.It is observed that with good infrastructure support this can be a very sustainable tourism option and may position India as a destination with unique offerings. This will also assist the farmers to supplement their incomes which are hugely dependent on monsoon offerings. The rural tourism model may be replicated in any part of the country with a local flavor as each region in India has a unique form of rural life and culture and cuisine. This will work as a tool for "counter urbanization' and for creation of employment opportunities at underdeveloped places.

\section{Books:}

\section{References}

[1]. Getz, D.Carlsen J. (2000) Characterstics and Goals of family and owner operated businesses in the rural tourism and hospitality sectors, $547-560$

[2]. Gilchrist, A. (2004). The well-connected community: a networking approach to community development: Community Development Foundation (Great Britain), The Policy Press, UK.

[3]. Godfrey, K., \& Clarke, J. (2000). The tourism development handbook: a practical approach to planning and marketing. London: Continuum.

[4]. lonely planet india

[5]. Malhotra, R.K. (1998) Growth and Development of Tourism. New Delhi: Anmol Publications Pvt.ltd, 8, 253

[6]. Murphy P E (1985) Tourism : A community approach

[7]. Richards, G., \& Hall, D. (Eds.). (2000). Tourism and sustainable community development. USA: Routledge

[8]. Salm, R.V. (1985) Integrating marine conservation and tourism. International Journal of Environmental Studies 25(4), 229-38.

\section{Research Paper}

[9]. Rural Tourism Development: constraints and possibilities with a special reference to Agri Tourism by Dr. R. Gopal, Ms. Shilpa Verma and Ms. Rashmi Gopinathan ( conference on Tourism in India-challenges ahead, 15-17 May 2008, IIMK)

[10]. Farm tourism in Punjab - a case study on the concept and its sustainability by Priyadarshan Lakhawat, sparkle ans spice,volune8(2011),p53-56

Websites

[11]. www.tourism.gov.in/statistics

[12]. www.punjabtourism.gov.in/farmtourism

[13]. www.oppapers.com-nainni/business and economy

[14]. http://tourism.gov.in/writereaddata/Uploaded/Guideline/072020110330849.pdf

[15]. www.lonelyplanet.com 